\title{
ESR による有機半導体界面のキャリアダイナミクス解析
}

\author{
松井 弘之 ${ }^{1}$-長谷川 達生 ${ }^{2,3}$ \\ ${ }^{1}$ 東京大学大学院 新領域創成科学研究科 嶫 277-8561 千葉県柏市柏の葉 5丁目 1-5 \\ 2産業技術総合研究所 フレキシブルエレクトロニクス研究センター 凿 305-8562 荻城県つくば市東 1丁目 1-1 \\ ${ }^{3}$ 東京大学大学院 工学系研究科 凿 113-8656 東京都文京区本郷 7 丁目 3-1
}

（2014 年 1 月 28 日受付；2014 年 2 月 12 日掲載決定）

\section{ESR Study of Carrier Dynamics in Organic Semiconductor Interfaces}

\author{
Hiroyuki Matsui $^{1}$ and Tatsuo Hasegawa ${ }^{2,3}$ \\ ${ }^{1}$ Department of Advanced Materials Science, The University of Tokyo, 5-1-5 Kashiwanoha, Kashiwa, Chiba 277-8561 \\ ${ }^{2}$ National Institute of Advanced Industrial Science and Technology (AIST), 1-1-1 Higashi, Tsukuba, Ibaraki 305-8562 \\ ${ }^{3}$ Department of Applied Physics, The University of Tokyo, 7-3-1 Hongo, Bunkyo-ku, Tokyo 113-8656
}

(Received January 28, 2014 ; Accepted February 12, 2014)

\begin{abstract}
Electron spin resonance (ESR) is an exceptionally sensitive tool to investigate unpaired electrons such as charge carriers in organic semiconductors. Here we review the ESR analyses of charge carrier dynamics in high-mobility organic transistors on the basis of motional narrowing effect : the Brownian motion of carriers makes the ESR spectrum narrower. Particularly, the evaluation of the charge transfer rate between trap sites and/or crystalline domains enables us to understand the charge transport mechanism from a microscopic perspective. We also compare the temperature dependence of the charge transfer rate and field-effect mobility in order to discuss what limits the performance of organic transistors.
\end{abstract}

KEYWORDS : organic semiconductor, field-effect transistor, thin film, electron spin resonance, motional narrowing

\section{1.は じめに}

パイ電子系有機分子からなる有機半導体は，シリコン 等によるエレクトロニクスを補完し得る有力な半導体と して，有機電界発光ダイオード（Organic Light-Emitting Diode, OLED)/有機薄膜太陽電池 (Organic Solar Cell, OSC) /有機薄膜トランジス夕（Organic Thin-Film Transistor, OTFT）などへのデバイス化を中心に，基礎から製 品化に至る幅広い分野で研究開発が盛んに行われてい る。なかでも OTFT は, 近年, 優れた特性を示す半導体 材料が数多く見いだされ，さらに溶液法や印刷法によっ て製膜する手法が開発されるなど, 研究が大きく進展し つつある ${ }^{1,2)}$ 。

OTFT では，有機半導体層内のゲート絶縁層との界面 近傍を流れるキャリアがデバイス動作を担うため，表

E-mail : h-matsui@k.u-tokyo.ac.jp
面/界面の有機分子の配列様式（薄膜モルフォロジー） が，デバイス特性を大きく左右する。このため表面科学 の知見が大きな威力を発揮すると期待されるが，その一 方で, 有機半導体の薄膜モルフォロジーと, これにより 作製した OTFT の特性との微視的な相関は，これまで必 ずしも明らかではなかった ${ }^{3)}$ 。本稿では, 有機半導体界 面におけるキャリアの微視的な動きを調べる手法とし て, ゲート電圧によって蓄積したキャリアによる電子ス ピン共鳴スペクトルを用いる最近の研究について紹介し たい。

\section{2. 有機トランジスタの電界誘起 ESR}

\section{1 有機半導体のキャリアと電子スピン共鳴}

最も典型的な OTFT のデバイス構造を Fig. 1 (a) に 模式的に示す。デバイスは, ゲート電極層/ゲート絶縁 層/有機半導体層/ソース・ドレイン電極層による多層構 造からなる。有機半導体層には, 一般にもともとキャリ 


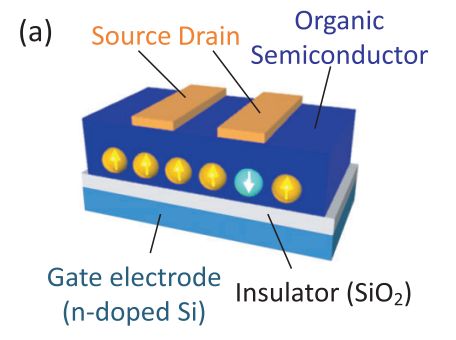

(b) intrinsic

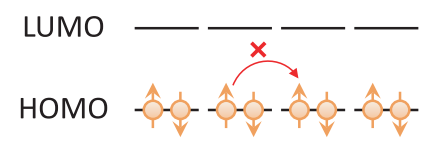

(c) n-doped

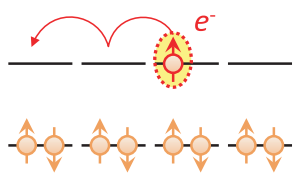

(d) p-doped

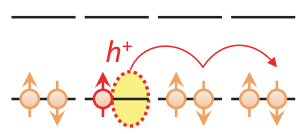

Fig. 1. (color online). Carrier doping of organic semiconductors.

アを持たない真性半導体が用いられる。ゲートーソース 間に正（または負）の電圧を加えると, コンデンサと同 じ原理で, 電子（または正孔）のキャリアが有機半導体 層内に蓄積される。ドレインーソース間へのバイアス印 加により, 蓄積されたキャリア数に比例した電流が層界 面に沿う方向に流れ，デバイスが動作する。有機半導体 としては，有機分子が層状に規則正しく配列した多結晶 薄膜や薄層単結晶などにおいて, 優れたデバイス特性 (キャリア移動度) が得られることが明らかになってい る。この辺りの事情は, アモルファス性の有機半導体が 多く用いられる OLED（電流は層面に垂直な方向に流れ る）とは対照的である。

有機半導体層を構成する有機分子は, 通常, 中性状態 で最高占有分子軌道 (Highest Occupied Molecular Orbital, HOMO）まで 2 個ずつ電子を収容し, 最低非占有分子 軌道（Lowest Unoccupied Molecular Orbital, LUMO）から 上は電子のない空軌道である（Fig. 1 (b))。隣接分子間 のパイ電子相互作用によって, HOMOによる価電子バ ンド，および LUMOによる伝導バンドが形成される。 ゲート電圧により有機半導体層内に蓄積された電子や正 孔は，Fig. 1 (c)（d）のように各分子軌道に収容され， 分子間の相互作用（すなわちバンド）を介して比較的自 由に動き回ることができる。

一方, Fig. 1（b）（c）を電子スピンの観点から眺めて みると, 有機半導体層内では, ゲート電圧によって蓄積 されたキャリアのみが不対電子に由来する有限の磁気モ ーメントを持つことがわかる。この電子磁気モーメント の磁場やマイクロ波に対する応答を観測するのが電子ス

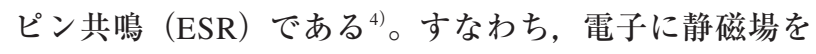
加えると, 上向きスピンと下向きスピンは異なるエネル

(a)

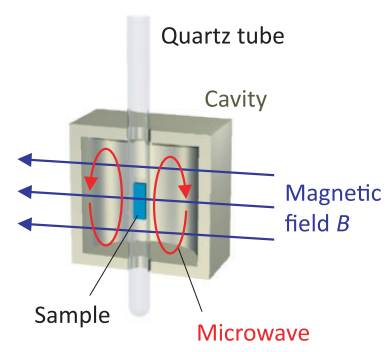

(b)

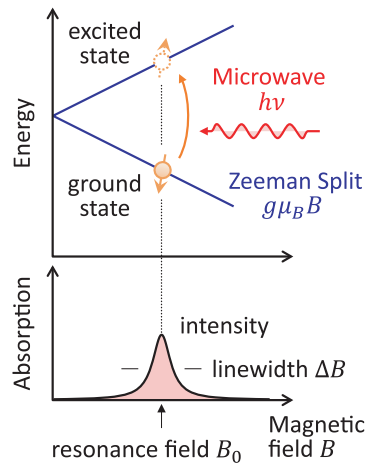

Fig. 2. (color online). (a) Schematics and (b) the principle of ESR measurement.

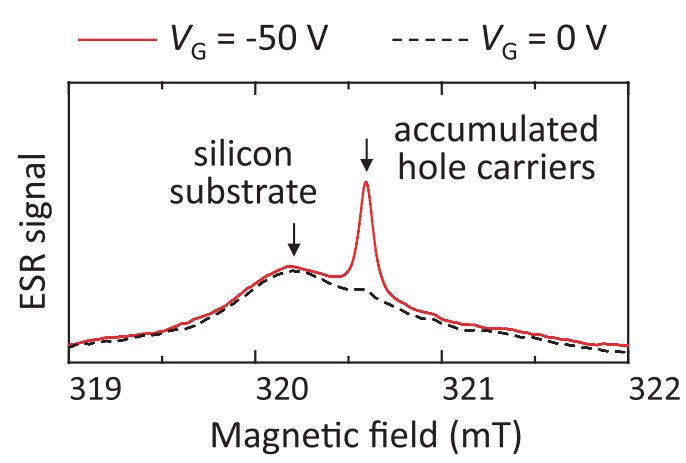

Fig. 3. (color online). Field-induced ESR spectra of a PBTTT TFT.

ギー状態となる Zeeman 分裂を起こす $($ Fig. 2)。分裂幅 は磁場 $B$ に比例し, $g \mu_{\mathrm{B}} B$ で与えられる。ここで $g=$ 2.0023 は $g$ 因子と呼ばれる無次元定数, $\mu_{\mathrm{B}}=9.3 \times 10^{-24}$ $\mathrm{J} / \mathrm{T}$ はBohr 磁子である。ここにマイクロ波を照射する と, 共鳴条件

$$
h \nu=g \mu_{\mathrm{B}} B
$$

を満たす場合に電子スピンはマイクロ波に強く応答し, スピンの向きを変える遷移, すなわち電子スピン共鳴 （ESR）が生じる。キャリアのない真性半導体ではこの ような ESR は観測されないため, 電界誘起によって有 機半導体層内に蓄積されたキャリアによる ESR のみが 選択的に観測されることになる (Fig. 3)。

以上のように, 電界誘起 ESR の測定原理自体はシン プルであり, 有機半導体以外の半導体材料にも適用可能 に思えるが, 実は電界効果型トランジス夕に扔いて, ゲ 一ト電圧により蓄積されたキャリアを ESRにより捉え た例は OTFT 以外にはない。その理由は, 界面にのみ蓄 積されるキャリア量は絶対量としてはごく僅かであり観 測自体が容易ではない一方で, 有機半導体は磁性不純物 がきわめて少なく, また軽元素からなるため電子スピン 
の緩和時間が長く，他の材料系と比べはるかに鋭い ESR スペクトルを示すことから, きわめて高感度の検 出が可能なためである。

OTFTを用いた電界誘起キャリアの ESR 測定は, 2004 年に丸本・黒田らによって報告され ${ }^{5 \sim 7)}$, 有機半導 体界面近傍に蓄積されたごく僅かのキャリアの検出が可 能なことが初めて示された。また同氏らにより, ESR 信号で捉えたスピン数がゲート絶縁層の静電容量にもと づくキャリア数と一致すること, スペクトルの磁場印加 方向依存性による分子配向解析が可能なことや, キャリ アの空間広がりなどに関する議論が行われた。さらに 我々は, 移動度が比較的高い OTFT を用いると, OTFT 内に蓄積したキャリアの動的性質を反映した「運動によ る先鋭化効果」が見られることを見いだし，これをもと にデバイス動作に直結するキャリア輸送機構の議論が可 能なことが明らかになった ${ }^{8)}$ 。

\section{2 キャリア運動によるスペクトル先鋭化}

ここでは, 電界誘起 ESR の実験結果を議論するため の前提として, ESR スペクトルの運動による先鋭化効 果について簡単に述べておきたい。まず電子スピン（キ ヤリア）が止まっている場合を考える。マイクロ波の周 波数を固定し, 磁場の掃引により $B=h \nu / g \mu_{\mathrm{B}}$ の共鳴条 件でマイクロ波吸収が起こるとする。ESR スペクトル

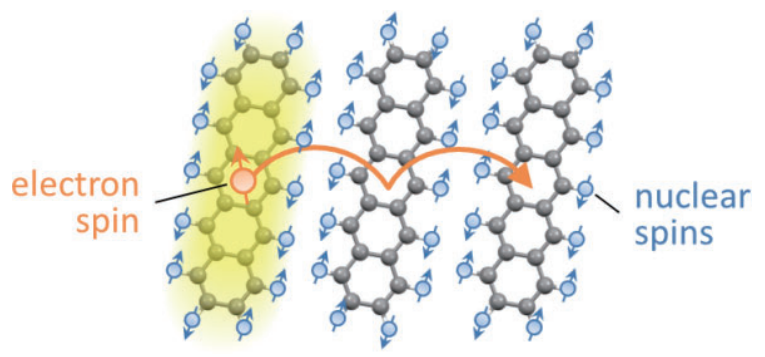

Fig. 4. (color online). An electron spin moving through randomly-oriented nuclear spins.
は，実際は前記の共鳴条件の近傍で Fig. 3 に示す有限の 線幅を持つが, その主な原因の一つに, 材料を構成する 多数の原子が持つ核スピンのランダム配向による不均一 幅がある（Fig. 4)。たとえば有機半導体内のプロトン核 スピンは, 電子スピンに対して 0.1〜 $1 \mathrm{mT}$ 前後の局所磁 場 $\Delta B_{\text {local }}$ として作用するため, 各々の電子スピンの共鳴 条件は, 場所ごとに異なる $B=h \nu / g \mu_{\mathrm{B}}-\Delta B_{\text {local }}$ となり, これらの総和として観測される ESR スペクトルは, $\Delta B_{\text {local }}$ の確率分布を反映した形状を示すと考えられる。

このような不均一な場の中で, 電子スピン（キャリ ア）が素早く移動する場合を考えると， $\Delta B_{\text {local }}$ は時々 刻々と変化するが, 実効的にはその変動をある時間幅で 平均化した磁場を感じているとみなすことができる ${ }^{9,10)}$ 。 平均化した磁場は元の局所磁場 $\Delta B_{\text {local }}$ よりも小さくなる から, その確率分布である ESR スペクトルの幅も小さ くなる。これが運動による先鋭化効果である。ただ先鋭 化効果はいつでも現れるわけではなく, 電子スピンの運 動の速さがある閾值を超えた場合にのみ観測にかかる。 その条件は, 電子スピンが単位時間に局所磁場の異なる 場所へ移動する確率（飛び移り頻度） $k$ を用いて $k>\gamma$ $\left(\left\langle\Delta B_{\text {local }}{ }^{2}\right\rangle\right)^{1 / 2}$ と表される。ここで $\gamma=1.8 \times 10^{11} \mathrm{~T}^{-1} \mathrm{~s}^{-1}$ は電子の磁気回転比である。 $\Delta B_{\text {local }}$ は典型的に $0.1 \sim 1$ $\mathrm{mT}$ 程度であるから, 閾值はお拈よそ $10^{7} \sim 10^{8} \mathrm{~s}^{-1}$ であ る。電子スピンの移動が閾值より遅いとスペクトル先鋭 化は起きない。これに対し, 電子スピンの移動が闇值よ り速くなると ESR スペクトルは先鋭化し始め, その線 幅は $k$ に反比例する。それ故, 先鋭化効果による線幅変 化の測定によって, キャリア運動の速さ（サイト間の飛 び移り頻度）を見積もることができる。

\section{3. 薄膜グレイン内のキャリア輸送}

\section{1 ESR 線幅の温度変化}

Fig. 5 (b) に，4 種類の OTFT について ESR 線幅の温 度依存性を調べた結果を示す ${ }^{8,11,12)}$ 。どの材料にも共通 (a)

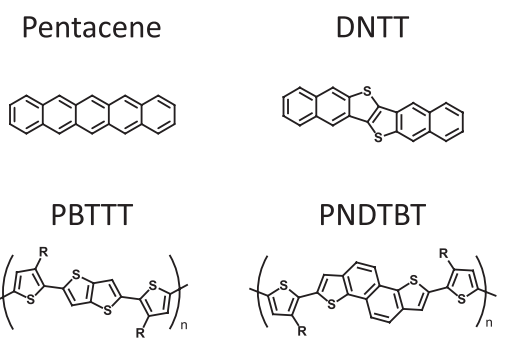

(b)

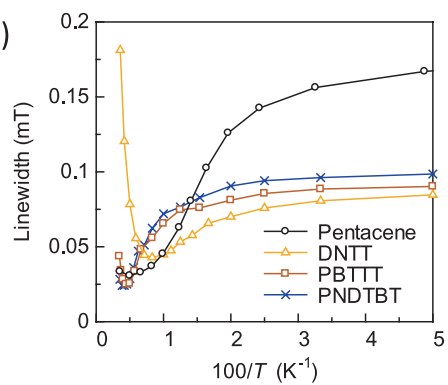

(c)

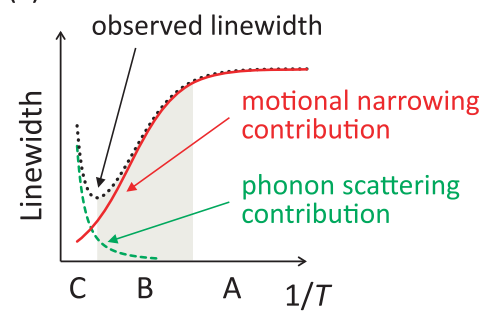

Fig. 5. (color online). (a) Molecular structures of pentacene, DNTT, PBTTT and PNDTBT. (b) Temperature dependence of ESR linewidth. (c) Schematics of motional narrowing and phonon scattering contributions to linewidth. 
する特徴として, 温度変化の挙動が大きく三つの領域に 分けられることがあげられる。眓右の低温領域（Fig. 5 (c) の A）では, 線幅は温度にあまり依存しない。すな わち先鋭化効果が見られないことから，キャリアはトラ ップに長時間（>10 ns）束縛され，ほとんど動いてい ないと考えられる。次に $50 \mathrm{~K}$ から $200 \mathrm{~K}$ くらいまでの 中温領域（B）に扔いては, 線幅は温度上昇とともに先 鋭化する。これはキャリアがトラップから熱的に解放さ れ，結晶中を動き始めたことによる先鋭化効果と考えら れる。この温度領域ではスペクトル形状は Lorentz 型で あり, またマイクロ波強度の増加に伴う線幅変化から, 低温に向かって徐々に不均一幅に変化していく様子が確 かめられた。より高温領域 (C) では, 領域（B）とは 逆に, 温度上昇に伴う線幅増加が見られる。これはもと もとキャリアを持つ分子性導体などで見られる挙動と類 似しており, 電子スピンのフォノン散乱による寿命幅の 温度変化によるものと考えられる。

\section{2 キャリアトラップ間の飛び移り頻度}

運動による先鋭化効果が生じているとき, キャリアの 飛び移り確率 $k_{1}$ は, 各温度の ESR 線幅 $\Delta B$ から以下の ように求められる ${ }^{9,10)}$ 。

$$
k_{1}=\gamma\left\langle\Delta B_{\text {local }}{ }^{2}\right\rangle / \Delta B
$$

$\left\langle\Delta B_{\text {local }}{ }^{2}\right\rangle$ は, キャリアが止まった領域 $\mathrm{A}$ の線幅から求め ることができる。(2)式によりキャリアの飛び移り頻度 を見積もった結果を Fig. 6 (a) に示す。飛び移り頻度 が $10^{7} \sim 10^{9} \mathrm{~s}^{-1}$ であることから, キャリアは一つのサイ 卜に拈よそ1〜100 ns の時間滞在していることがわか る。また温度上昇とともに, 半導体の種類によらず飛び

(a)

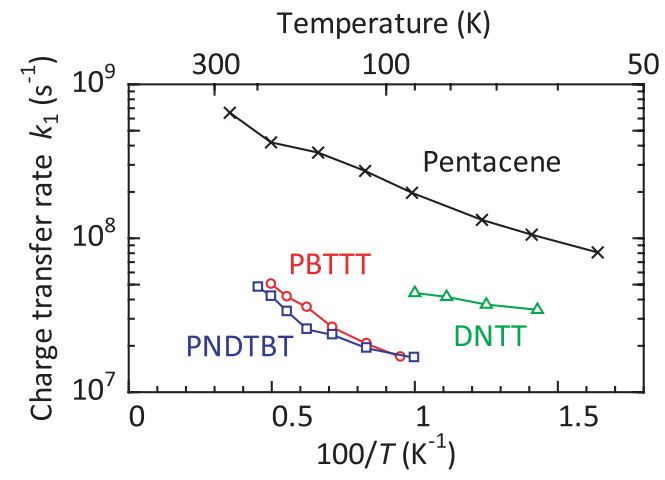

(b)

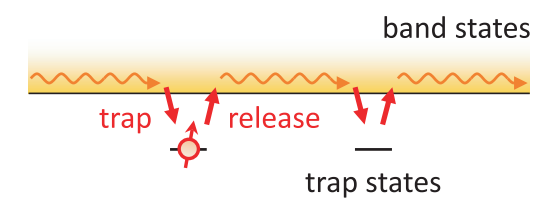

Fig. 6. (color online). (a) Intradomain charge transfer rate $k_{1}$ evaluated by Eq.(2). (b) Schematics of trap \& release model.
移り頻度が増加するものの, その温度変化は比較的緩や かであり, 活性化エネルギーはおよそ 5 2 $2 \mathrm{meV}$ 程度 と見積もられた。

以上の飛び移り頻度とは, どのようなキャリア運動を 表したものだろうか？ たとえば隣接分子間の電荷の飛 び移り頻度を表す Marcus 理論に従えば， $k_{\text {Marcus }}$ は

$$
k_{\text {Marcus }}=\frac{t^{2}}{\hbar}\left(\frac{\pi}{\lambda k_{\mathrm{B}} T}\right)^{1 / 2} \exp \left(-\frac{\lambda}{4 k_{\mathrm{B}} T}\right)
$$

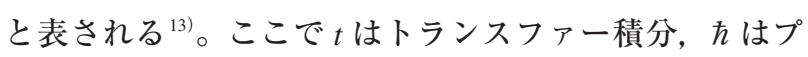
ランク定数, $\lambda$ は荷電に伴う分子歪による分子の再配列 エネルギー， $k_{\mathrm{B}}$ はボルツマン定数， $T$ は温度である。ペ ンタセン（Fig. 5（a)）などの典型的な有機半導体では, $k_{\text {Marcus }}=10^{13} \sim 10^{14} \mathrm{~s}^{-1}$ 程度であり, ESR から得られた值 $10^{7} \sim 10^{9} \mathrm{~s}^{-1}$ はこれよりもはるかに小さい。それ故, 塞 際の OTFT に打けるキャリアは分子内歪みの効果で局在 しているというょり, 久陥などの外的要因によって弱く トラップされていると考えるべきである ${ }^{14)}$ 。実際，飛び 移り頻度の活性化エネルギーは室温での熱エネルギー $\left(k_{\mathrm{B}} T=25 \mathrm{meV}\right)$ と比べて小さく, 弱いキャリアトラッ プの平均的なトラップ深さを反映していると考えられ る ${ }^{15)}$ 。結果として, キャリアは Fig. 6 (b) に示すように 熱的にトラップへの束縛と解放（trap and release）を繰 り返しながら移動していると考えられる ${ }^{16)}$ 。トラップ間 の移動時に経由する中間状態がどのようなものなのか, ESR の実験からは明らかでないが, Hall 効果の測定結 果などから, バンド伝導を経由していると考えられ る17。

\section{4. 薄膜グレイン間のキャリア輸送}

\section{1 一軸性多結晶薄膜と ESR スペクトル}

浅いトラップを介したキャリア輸送のモデル（Fig. 6 （b））は, 半導体層全体が単結晶で, 分子の僅かなずれ などによりトラップが形成された状況を表していると考 えられる。実際, 多結晶薄膜を用いた多くの OTFT で は, キャリア移動度の活性化エネルギーは 50〜 $100 \mathrm{meV}$ と大きく, Fig. 6 (a) で見られる活性化エネルギーとは 一致していない。その理由として, 多結晶薄膜の結晶粒 界による影響が考えられる ${ }^{18)}$ 。電界誘起 ESR 法では, 1 軸配向性の多結晶薄膜を用いることにより，このような 結晶粒界をまたぐキャリアの飛び移りについても調べる ことが可能である ${ }^{12)}$ 。

先述したように比較的高いデバイス特性を示す OTFT は, 有機分子が層状に規則正しく配列した層状結晶性を 示す材料で得られる。このような場合の多結晶薄膜は, Fig. 7 (a) に示すように 1 軸配向している。ここでは基 板面に垂直な結晶軸を $c$ 軸とする $(a, b$ 軸は基板面内 

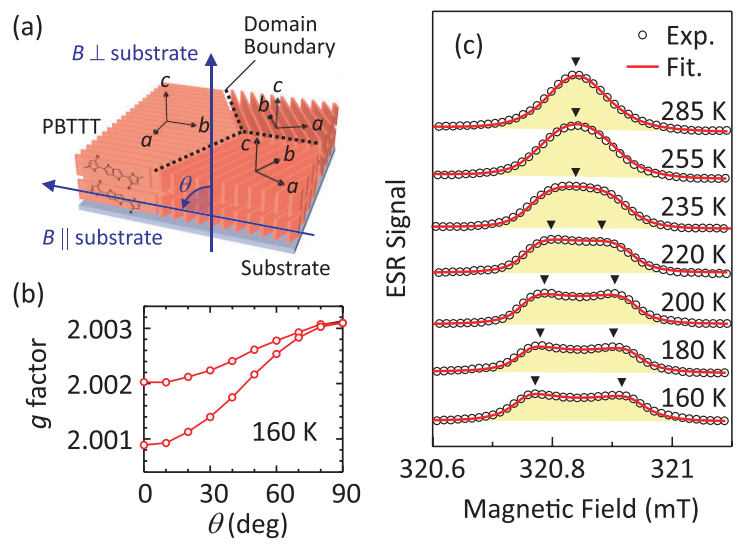

Fig. 7. (color online). (a) Molecular orientation of PBTTT multi-domain film. (b) Angle dependence of $g$ factor. (c) Interdomain motional narrowing of ESR spectra at $B \|$ substrate. Semiconductor is PBTTT.

でランダム配向している)。一般に各結晶ドメインは, 磁場印加方向に対して $g$ 值, すなわち共鳴磁場の值が異 なる磁気異方性を示す。磁場を基板面に垂直に印加する とき, 磁場は常に $c$ 軸と平行になるから, すべての結晶 ドメインから同一の ESR 信号が得られる。実際，Fig. 5,6 の結果はそのような実験配置で得られている。一 方, 磁場を基板面に平行に印加すると, 磁場は各結晶ド メインに対して $a b$ 面内の様々な方向を向くことになる。 実際に磁場を基板に平行に加えたときの ESR スペクト ルの温度変化を Fig. 7（c）に示す。室温では単一のピ ーク構造が観測されているが, 降温とともにスペクトル は二つのピークに分裂している。これらピークは，それ ぞれ $a$ 軸，および $b$ 軸方向に印加した場合の共鳴信号に 対応する。なおこのようなピーク分裂は, スピン一軌道 相互作用の異方性が比較的大きな分子でのみ観測される ことに注意しておきたい。典型的には硫黄など原子番号 の大きな元素を含む分子 (Fig. 5 (a) の DNTT と PBTTT）の場合にこのようなピーク分裂が観測される が, ペンタセンのように炭素と水素のみからなる分子で は，スピン一軌道相互作用は小さく，上述したピーク分 裂は見られない(19)。

\section{2 グレイン間のキャリアの飛び移り頻度}

Fig. 7 (c) の室温のスペクトルを見ると, そのピーク 位置は, 低温で分裂した二つのピークのちょうど中央付 近に位置することがわかる。またそのスペクトル線幅か ら, スペクトルの成り立ちは, 二つのピークの単純な足 しあわせでないことは明らかである。このようなスぺク トルの温度変化は, キャリアが結晶ドメイン間を飛び移 ることによって異方性が平均化され，これにもとづく運 動による先鋭化効果によって理解することができる。

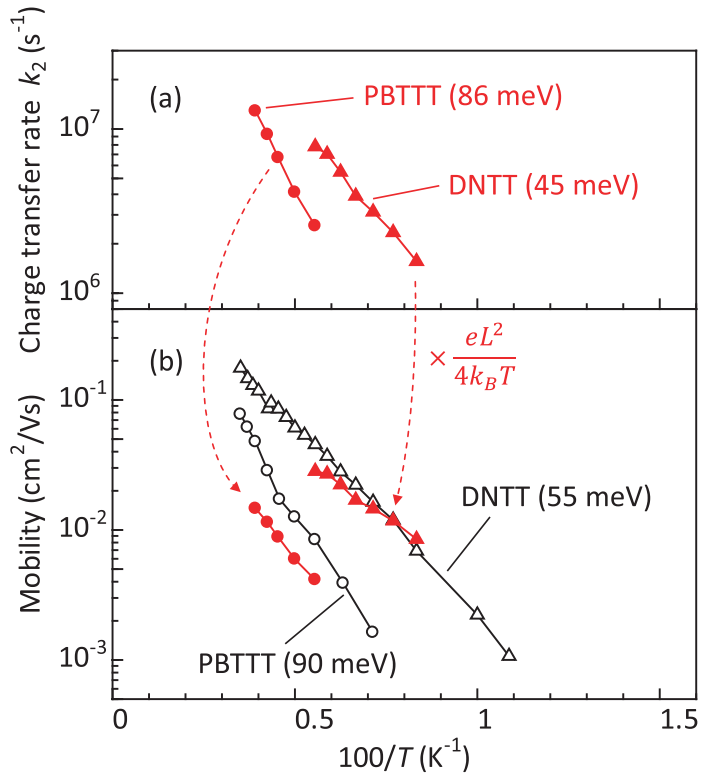

Fig. 8. (color online). (a) Interdomain charge transfer rate $k_{2}$ evaluated by fitting analysis. (b) Mobility calculated from transfer curve and Eq.(3).

このような 2 種の局所磁場の平均化によって生じる先 鋭化効果の解析には, 理論曲線によるフィッティング解 析が必要である。Fig. 7 (c) の実線は, フィッティング 結果を示しており，実験スペクトルを良く再現している ことがわかる。さらにこれにより, 結晶ドメイン間の飛 び移り頻度を見積もることができる。Fig. 8 (a) に DNTT および PBTTT の場合のキャリアの結晶間飛び移 り頻度 $k_{2}$ の温度依存性を示した。 $k_{2}$ は, 前節で見積も った結晶内のトラップ間の飛び移り頻度 $k_{1}$ と比べ, 1 桁程度小さい。また $k_{2}$ の温度依存性から見積もった活 性化エネルギーは, DNTT では $45 \mathrm{meV}$, PBTTT では 86 $\mathrm{meV}$ であり, 結晶粒界に大きなエネルギー障壁がある ことを示唆している。

上記で得られたキャリアの飛び移り頻度 $k_{2}$ をもとに, 多結晶薄膜の輸送機構をモデル化してみよう。1 回あた りの移動距離 $L$ (飛び移り距離) が決まれば，2 次元酔 歩モデルによって移動度は

$$
\mu=e L^{2} k_{2} / 4 k_{\mathrm{B}} T
$$

と見積もられる ${ }^{20)}$ 。ここで $L$ は結晶ドメインのサイズと 同程度であり, AFM 像から DNTT と PBTTTでともに $L=200 \mathrm{~nm}$ 程度であると仮定した。Fig. 8（b）に，上記 の仮定のもとで, ESRの運動による先鋭化から見積も った移動度を示す。得られた值は，同じ OTFTについて 伝達特性から求めた移動度とほほ一致している。これよ り多結晶 OTFT における実効移動度は, ほぼ結晶粒界を 律速として決まることが確かめられた。特に, 高結晶性 
ポリマー半導体として知られる PBTTTでは，原子間力 顕微鏡（AFM）等による表面モルフォロジー観察では ドメイン構造は識別できないにもかかわらず, 低分子系 の DNTT と同様に, 結晶粒界が大きな律速要因となっ ていることが証拠づけられる。

\section{5. を め}

以上，有機半導体界面に蓄積したキャリアが持つ電子 スピンを鋭敏なプローブとして活用することにより， OTFT のデバイス動作を決定づける微視的なキャリアダ イナミクスを調べた研究について述べた。特に, 電界誘 起 ESR スペクトルに見られる運動による先鋭化効果の 解析をもとに, 有機半導体界面におけるキャリア輸送 が, 有機半導体結晶ドメイン内における浅いトラップヘ のトラップと解放を繰り返す輸送と, 結晶ドメイン間の 高いエネルギー障壁 $\left(k_{\mathrm{B}} T\right.$ の数倍) をまたぐ輸送という 二つの観点から理解できることを明らかにした。これら の知見が, OTFT のさらなる高度化とともに, より広く 表面科学の多彩な取り組みに資することがあれば幸いで ある。

\section{文献}

1) J. Takeya et al. : Appl. Phys. Lett. 90, 102120 (2007).

2) H. Minemawari, T. Yamada, H. Matsui, J. Tsutsumi, S.
Haas, R. Chiba, R. Kumai and T. Hasegawa : Nature 475, 364 (2011).

3) T. Sakanoue and H. Sirringhaus : Nat. Mater. 9, 736 (2010).

4) 伊達宗行 : “電子スピン共鳴” (培風館, 1997).

5) K. Marumoto et al. : J. Phys. Soc. Jpn. 73, 1673 (2004).

6) K. Marumoto et al. : J. Phys. Soc. Jpn. 74, 3066 (2005).

7) K. Marumoto et al. : Phys. Rev. Lett. 97, 256603 (2006).

8) H. Matsui et al. : Phys. Rev. Lett. 100, 126601 (2008).

9) アブラガム : “核の磁性 (下)”, 第 10 章 (吉岡書店, 2005).

10) P.W. Anderson : J. Phys. Soc. Jpn. 9, 316 (1954).

11) H. Matsui, A.S. Mishchenko and T. Hasegawa: Phys. Rev. Lett. 104, 056602 (2010).

12) H. Matsui et al. : Phys. Rev. B 85, 035308 (2012).

13) R.A. Marcus : Rev. Mod. Phys. 65, 599 (1993).

14) W.L. Kalb et al. : Phys. Rev. B 81, 155315 (2010).

15) M.E. Gershenson, V. Podzorov and A.F. Morpurgo : Rev. Mod. Phys. 78, 973 (2006).

16) G. Horowitz and P. Delannoy: J. Appl. Phys. 70, 469 (1991).

17) T. Uemura et al. : Phys. Rev. B 85, 035313 (2012).

18) S. Verlaak, C. Rolin and P. Heremans : J. Phys. Chem. B 111, 139 (2007).

19) H. Matsui et al. : Mater. Res. Soc. Symp. Proc. 1436, K09-09 (2012).

20) M.F. Calhoun, C. Hsieh and V. Podzorov : Phys. Rev. Lett. 98, 096402 (2007). 